\title{
David Chidester: An Appreciation
}

\author{
Edward T. Linenthal \\ etl@indiana.edu
}

When the editors asked if I would write a short reflection on my long and enduring friendship with David Chidester for a book honoring David's brilliant career, I of course said, 'Yes'. David and I met in 1974 as graduate students at the University of California, Santa Barbara, in the department of Religious Studies. Along with two good friends and fellow graduate students, Jim McNamara and Deborah Sills-Gunn - who left us far too early - the four of us made up the Board of Directors (acknowledged in every one of David's books). So many years later, we still have not yet decided what we are directing, but even with Deb's empty chair, we remain a board-of-directors-in-waiting. We all shared wonderful times at the warm and inviting home of Walter and Lois Capps. Deb, David, and I spoke at the university's memorial service after Walter's sudden death in 1997, and David and I loved that we were able to present him with a copy of our co-edited book, American sacred space, dedicated to Walter.

I remember our team-teaching in 1978, Religion in America today, when the events at Jonestown challenged the adequacy of the field's interpretive frameworks. David wrote in his 2003 Prologue for the revised edition of Salvation and suicide: Jim Jones, the Peoples Temple, and Jonestown: 'I was not prepared when entering the classroom on that morning to make sense out of the event'. The first edition, published in 1988, he tells us, 'was my attempt to understand not only the specific case of Jonestown but also questions about religion, violence, and America'. His central question, he informs his readers, 'for those who died willingly, [is] how could they have died meaningfully within the religious worldview that was developed in the Peoples Temple and Jonestown?' (Chidester 2003:xvii-xviii). Significantly, David wrote Salvation and suicide after he moved to apartheid South Africa 
and, he writes, 'the real subject matter of the book was about what America would look like if it looked like South Africa' (Chidester 2003:xxii).

I remember how the book jerked me out of predictable, formulaic ways of 'making sense' of horrific events and how, in this case, the deployment of popular and irresponsible rhetoric of 'cults' and 'brainwashing' was itself an act of violence. Mindful of Salvation and suicide, I have tried in my own work to be sensitive to the rhetorics of containment cloaked in the guise of 'understanding'. Further, David demonstrates how careful cultural analysis is a compellingly humanizing enterprise. Victims were, he observes, 'depicted as not American, not religious, not sane, and ultimately not human. In the context of all this denial, distancing, and even demonization, I have tried to recover a sense of the humanity of the people who died in Jonestown' (Chidester 2003:xix).

For many years while teaching at the University of Wisconsin, Oshkosh, I would begin our introductory course with David's chapter Perspectives on an event, focusing mainly on the section, Death rituals of exclusion and inclusion. How better to yank students who thought about religion as largely a matter of belief and rules of living into religious worlds deeply engaged with sacrificial/redemptive violence, with bodies, with events subversive of cherished convictions about religion as by definition humanizing? In my own struggles with various representations of violence at battlefields, at Holocaust memorial sites, in bitterly contested commemorations of Hiroshima and Nagasaki, in the aftermath of the Oklahoma City bombing, and the 2011 terrorist attacks in Norway - Salvation and suicide has remained a lodestar for me.

I recall a handwritten note David sent me after I asked him to read a chapter - on Gettysburg, I think - in what would become Sacred ground: Americans and their battlefields. David has the gift of understanding what I am about better than I do myself. He liked the chapter, he wrote, because I had demonstrated how dynamic was the life of this place through processes of veneration, defilement, and redefinition. As soon as I read his words, I knew that he had captured the crucial categories that were the ideal interpretive framework for the book. Consequently, the first sentence reads: 'This book is about the processes of veneration, defilement, and redefinition that have characterized public attitudes toward America's most famous battlefields: the Lexington Green and Concord's North Bridge, the Alamo, Gettysburg, the Little Bighorn, and Pearl Harbor'. Thanks, D, you are the best! 
I think of David and Careen's wedding during an American Academy of Religion meeting in Anaheim - presided over by the incomparable Jim McNamara - and of David and Careen's visits to Oshkosh, Wisconsin, and Bloomington, Indiana, that combined business - David's lectures - with time for David, Careen, Ulla and I to eat, drink, and be merry. In 1990, David was a keynote speaker at a conference I organized at the University of Wisconsin, Oshkosh, named Religion, racism, violence: South Africa \& North America. I arranged a busy Wisconsin lecture tour for David after the conference. He spoke about some of the case studies in Shots in the streets: Violence and religion in South Africa. At the University of Wisconsin, Stevens Point, he offered a lecture that eventually became the basis for the chapter, Sacrificial religion, in Authentic fakes: Religion and American popular culture. David offers a 'curious parallel' between Jim Jones and Ronald Reagan: 'Jones wanted children to die to save them from capitalism, while Ronald Reagan wanted children to die to save them from communism'. (Readers will appreciate the comparison by reading Reagan's chilling convictions expressed in his oft-cited speech to the National Association of Evangelicals on March 8, 1983, quoted in David's chapter.) 'Although engaged in different strategic projects', David writes, 'the sacrificial negotiations conducted by Jim Jones and Ronald Reagan were enacted in the same American political economy of the sacred in which person, place, and power can be negotiated through inherently violent acts of human expenditure' (Chidester 2005:92, 110). I remember being nervous before David's talk, which I feared would be intolerably heretical to many in the audience. To my pleasant surprise, people listened intently and openly.

This provocative comparison is only one example of David's ability to engage in serious play. He has such a wicked smart sense of humor, of irony, and incongruity. It is hard for me to imagine, for example, another historian of religion writing in playful seriousness about the First church of the last laugh, dedicated to St. Stupid. 'As the church observes', David writes, 'its ritualized stupidity preserves the original religion. Since religions are based on guilt and fear, which are stupid, stupidity must have come first. The annual St. Stupid's Day parade, in the view of the First Church of the Last Laugh, practices the most basic religion of humanity'. This is only one small example of why it has been so much damn fun to be David's friend all these years. I hope it continues: Great books, great stories, and many more years for it all. 


\section{References}

Chidester, D. 2003. Salvation and suicide: Jim Jones, the Peoples Temple, and Jonestown. Rev. ed. Bloomington: Indiana University Press.

Chidester, D. 2005. Authentic fakes: Religion and American popular culture. Berkeley: University of California Press.

Edward T. Linenthal

Department of History Indiana University Bloomington etl@indiana.edu 